\title{
Drying process of Lentinula edodes: Influence of temperature on $\beta$-glucan content and adjustment of mathematical models
}

\section{Processo de secagem de Lentinula edodes: Influência da temperatura no teor de $\beta$-glucanas e ajuste de modelos matemáticos}

\author{
Thaynã Gonçalves Timm¹ (D), Rafaely Zenni Pasko' ${ }^{1 D}$, Ceci Sales da Gama Campos $^{2}$ (D), \\ Cristiane Vieira Helm ${ }^{3}$, Lorena Benathar Ballod Tavares ${ }^{1 *}$ (D)
}

'Universidade Regional de Blumenau/FURB, Blumenau, SC, Brasil

IInstituto Nacional de Pesquisas da Amazônia/INPA, Manaus, AM, Brasil

${ }^{3}$ Empresa Brasileira de Pesquisa Agropecuária/EMBRAPA, Centro de Pesquisa Florestal, Colombo, PR, Brasil

*Corresponding author: lorena@furb.br

Received in October 21, 2019 and approved in December 12, 2019

\begin{abstract}
The importance of the functional properties of edible mushrooms as a food product has been increasing and several studies have emerged to address this issue. However, the application of a conservation process is required since this is a product with a high moisture level. The aim of this study was to investigate the drying kinetics of shiitake Lentinula edodes mushrooms by means of the construction of drying curves, the mathematical modeling of the drying curves, and correlating the data obtained with the $\beta$-glucan content in order to observe the influence of temperature on its content. The drying temperatures of $35^{\circ} \mathrm{C}, 45^{\circ} \mathrm{C}$ and $55^{\circ} \mathrm{C}$ were applied to construct the drying curves and the $\beta$-glucan contents of the samples were quantified. Mathematical modeling was performed in order to identify the best model for the representation of the product moisture loss during the drying period. The equilibrium humidity values were $0.346 \%$ for $35^{\circ} \mathrm{C}, 0.892 \%$ for $45^{\circ} \mathrm{C}$ and $0.875 \%$ for $55^{\circ} \mathrm{C}$, and the $\beta$-glucan contents showed no significant difference for the three temperatures analyzed, as confirmed by the Tukey test. Of the eight mathematical models fitted to the drying curves, the Page and the Midilli models provided the best results. Therefore, based on the findings, $55^{\circ} \mathrm{C}$ appears to be the optimum temperature for the Shiitake mushroom drying process in the studied conditions, as it provides the shortest drying time and the $\beta$-glucan content is maintained.
\end{abstract}

Index terms: Shiitake; health; drying curves; polysaccharide; dehydration.

\begin{abstract}
RESUMO
A importância do desenvolvimento de alimentos com propriedades funcionais provenientes de cogumelos comestíveis vem crescendo, surgindo assim diversas pesquisas para evolução desse mercado. No entanto é necessário a aplicação de procedimentos de conservação, pois se trata de um produto com elevado teor de umidade. O objetivo dessa pesquisa foi estudar a cinética de secagem do cogumelo shiitake (Lentinula edodes) por meio da construção de curvas de secagem, ajuste de modelos matemáticos à estas curvas e correlacionar os dados obtidos com o teor em $\beta$-glucanas para observar a influência da temperatura neste teor. Foram testadas as temperaturas de 35,45 e $55^{\circ} \mathrm{C}$ a partir de dados empíricos, construindo, assim, as curvas de secagem e quantificando o teor de $\beta$-glucanas das amostras. Posteriormente, foi realizada a aplicação de modelos matemáticos encontrados na literatura, identificando aquele que melhor represente a perda de umidade do produto durante o período de secagem. As umidades de equilíbrio resultaram em $0,346 \%$ para $35{ }^{\circ} \mathrm{C}, 0,892 \%$ para $45^{\circ} \mathrm{C}$ e 0,875 para $55^{\circ} \mathrm{C}$ e os teores de $\beta$-glucanas não apresentaram diferença significativa entre as três temperaturas estudadas, confirmadas a partir do teste de Tukey. Entre os oito modelos matemáticos ajustados aos dados experimentais, os modelos de Page e Midilli apresentaram os melhores resultados. Portanto, pode-se recomendar como temperatura de secagem de Shiitake $55^{\circ} \mathrm{C}$ nas condições estudadas, visto que esta resulta em menor tempo de secagem e mantêm o teor de $\beta$-glucanas.
\end{abstract}

Termos para indexação: Shiitake saúde; curvas de secagem; polissacarídeo; desidratação.

\section{INTRODUCTION}

In recent years, there has been increasing concern regarding issues related to food products destined for human consumption. This has enhanced the search for ingredients that promote health benefits. The awareness of consumers has increased, and they now seek healthy and nutritious food options with additional functions that promote wellbeing, combined with convenience and practical characteristics (Bigliardi; Galati, 2013). 
Consequently, developing products with added value, convenience, nutritional factors, variety and economic saving, has been perceived as important (Betoret et al., 2011). In this regard, attention has been directed toward edible mushrooms, which have been extensively studied (Helm; Coradin; Kestring, 2009).

Edible mushrooms contain significant quantities of proteins, dietary fiber, minerals and vitamins (Helm; Coradin; Kestring, 2009; Sari et al., 2017), $\beta$-glucan, hemicelluloses, essential amino acids and carbohydrates, such as chitin, glycogen, trehalose and mannitol, and have low caloric value and lipidic rates (Valverde; HérnandezPérez; Paredes-López, 2015; Henriques et al., 2016). They also contain numerous bioactive compounds with medicinal proprieties (Lenzi et al., 2018) and are used for prevention against sickness, including hypertension, hypercholesterolemia, cancer, and diabetes (Helm; Coradin; Kestring, 2009).

A notable edible species is Lentinula edodes (Berk) Pegler. It is known as Shiitake and is associated with large production and consumption volumes around the world (Sousa et al., 2019). This mushroom presents pleasant taste (Sousa et al., 2019), a considerable quantity of dietary fiber, proteins, carbohydrates, essential minerals and vitamins, and low amounts of fat and calories (Helm; Coradin; Kestring, 2009). Edodes is known as the most important $\beta$-glucan source from mushrooms. The $\beta$-glucans are macromolecules with action on the immunologic system (Sari et al., 2017; Wasser, 2017), since they are not synthesized in the human body (Sari et al., 2017), and thus have potential applications in the pharmacology field, nutraceutical products, and functional foods (Bach et al., 2017). The significant quantities of $\beta$-glucan in $L$. edodes has stimulated research and development in this area, especially because people prefer to consume fresh mushrooms. However, they are highly perishable and undergo rapid microbiology and biochemical changes (Rhim; Lee, 2011), and these characteristics represent obstacles for distribution and commercialization (Qi et al., 2014). Therefore, preservation methods are being developed in order to extend the mushroom shelf life, in particular that of Shiitake mushrooms (Qi et al., 2014; Rhim; Lee, 2011). Additionally, the study of the incorporation of shiitake into processed food or dietary supplements is gaining attention since there are few products of this type on the market (Chang; Wasser, 2012).

It is thus necessary to use appropriate preservation or conservation methods to ensure that nutrients will not be lost (Qi et al., 2014). Of the conservation processes available, drying (or dehydration) is a good alternative since it reduces significantly the product moisture content, maintains its quality, and provides a longer and safer shelf life with lower microorganism proliferation (Maisnam et al., 2017). In this process, the drying kinetics is crucial for the process optimization through the control of operational parameters (Salehi; Kashaninejad; Jafarianlari, 2017).

Although the drying conditions, the shelf life and the effects of the drying process on the quality of mushrooms have been widely studied, there has been little discussion on the L. edodes drying kinetics and influence of heat on the conservation of $\beta$-glucan or bioactive compounds, which are important to human health, during the drying processes. In this context, the aim of this study was to examine the drying kinetics of edodes through the construction of drying curves and quantifying the dietary fiber and $\beta$-glucan contents in the mushroom in order to verify the influence of the drying temperature on the conservation of $\beta$-glucan content prior to commercialization. In addition, mathematical models described in the literature were fitted to the drying curves, in order to describe the drying behavior of shiitake under the temperature and time conditions that allow the $\beta$-glucan content to be preserved. The results could be used to facilitate future experimental processes, establish an ideal drying time, and enable the appropriate selection of parameters important to industrial process.

\section{MATERIAL AND METHODS}

A fresh sample of the Shiitake mushrooms (L. edodes) - pesticide-free, originating from one lot (batch number 5413002730, Fungibras Ind. e Com. e Fungicultura Ltda, Botucatu - SP, Brazil), was purchased in a local supermarket (Blumenau - SC, Brazil) and washed with distilled water to prepare it for analysis. This was then used to study the drying kinetics and evaluate the mathematical models. The $\beta$-glucan and soluble dietary fiber contents were determined for the fresh sample as well as the samples that were dried.

\section{Mushroom drying}

The fresh mushrooms were cut into slices with a thickness of $0.5 \mathrm{~cm}$ and $10 \mathrm{~g}$ samples were weighed in a stainless-steel holder adapted to a real-time weighing system in which the balance was coupled to a drying oven with mechanical air circulation. The stainless-steel holder containing the sample remained suspended inside the oven and connected to the balance during the whole drying time (Figure 1). This system design allows the sample weight 
to be recorded during the drying period without removing it from the oven.

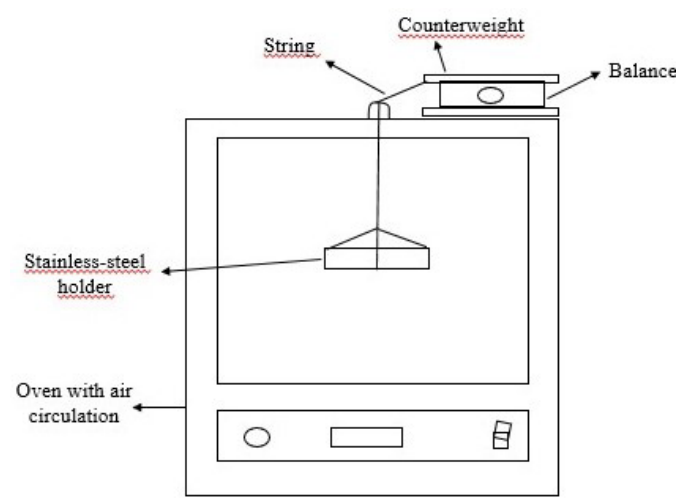

Figure 1: Real-time weighing system

The drying kinetics were investigated using $35^{\circ} \mathrm{C}$, $45^{\circ} \mathrm{C}$ and $55^{\circ} \mathrm{C}$ as the temperatures studied, based on previous research with other mushroom species (Wakchaure et al., 2010). In addition, it was considered that the soluble polysaccharide content decreases during drying processes carried out at $60^{\circ} \mathrm{C}$ (Wang; Zhang; Mujumdar, 2014 ), therefore, $\beta$-glucans, being polysaccharides, could be affected by temperatures higher than $55^{\circ} \mathrm{C}$. When the oven reached the steady state, samples were packaged onto the holder and mass measurements were started. The mass was recorded at 5-min intervals until it reached the equilibrium state when the mass remained constant. The data collected were used to calculate the equilibrium moisture and to fit the mathematical models. The dry sample was then submitted to analysis to determine the $\beta$-glucan and soluble dietary fiber content.

\section{Equilibrium moisture determination and drying curves}

Prior to determining the equilibrium moisture and constructing the drying curves, the values for the moisture content on a wet basis (U) and on a dry basis (X) were calculated for each study temperature using Equations 1 and 2 , respectively (Geankoplis, 1993).

$$
\begin{aligned}
& U(\% \text { bu })=\frac{\text { water mass }}{\text { total mass }} * 100 \\
& X(\% b s)=\frac{U}{100-U}
\end{aligned}
$$

where $\mathrm{U}$ is the moisture content on a wet basis and $\mathrm{X}$ is the moisture content on a dry basis.

The values obtained were then used to plot a graph of the values for moisture content on a dry basis (X) versus the drying period $(\mathrm{t})$. The polynomial equation was obtained, and its derivative was calculated to determine the point at which the moisture content is close to the equilibrium value when the drying rate tends to zero. The equilibrium moisture content is the lowest value attainable under certain drying conditions and it is defined as the moisture content when the vapor pressure of the water present in the sample has reached equilibrium with its surroundings (Duangkhamchan; Wiset; Poomsa-ad, 2013). The graph of the drying velocity $(-\mathrm{dX} / \mathrm{dt})$ versus moisture content on a dry basis (X) was plotted and the linear regression equation was obtained from the decreasing velocity period to calculate the equilibrium moisture $\left(\mathrm{X}_{\mathrm{e}}\right)$ (Geankoplis, 1993). Finally, the data were converted to dimensionless moisture $\left(\mathrm{X}_{\mathrm{r}}\right)$ using Equation 3 (expression for dimensionless moisture) (Geankoplis, 1993), which allows the normalized drying curves (moisture content ratio (MR) versus time) to be constructed for each study temperature and the fitting of the mathematical models.

$$
X_{r}=\frac{X-X_{e}}{X_{0}-X_{e}}
$$

where $\mathrm{X}$ represents the instantaneous moisture content on a dry basis, $\mathrm{X}_{\mathrm{r}}$ is the dimensionless moisture, $\mathrm{X}_{0}$ is the initial moisture content on a dry basis, and $\mathrm{X}_{\mathrm{e}}$ is the equilibrium moisture content on a dry basis obtained from the steady state of the drying process.

\section{Fitting of mathematical models}

In order to establish predictive equations for the drying process, the drying curves constructed from the experimental data were fitted to empirical and semiempirical mathematical models for each study temperature using non-linear regression. Several models have been proposed to study the thin layer drying kinetics of natural products (Zhang et al., 2016). The models selected (Table 1) were based on a study by Wakchaure et al. (2010) on mushroom drying kinetics. In these models, $\mathrm{Xr}$ represents the dimensionless moisture, the letters $\mathrm{a}, \mathrm{b}, \mathrm{k}$, and $\mathrm{n}$ are the model constants and $\mathrm{t}$ is the drying time. 
The values for the determination coefficient $\left(\mathrm{R}^{2}\right)$ obtained from the fitting were used to compare the models and to identify those that best represent the mushroom moisture loss during the drying period for each temperature.

Table 1: Mathematical models used to model the drying kinetics of $L$. edodes.

\begin{tabular}{|c|c|}
\hline Model & Equation \\
\hline Diffusion Approach & $X r=a e^{-k t}+(1-a) e^{-k b t}$ \\
\hline Newton & $X r=e^{-k t}$ \\
\hline Page & $\mathrm{Xr}=\mathrm{e}^{-\mathrm{ktn}}$ \\
\hline Handerson and Pabis & $X r=a e^{-k t}$ \\
\hline Two-term exponential & $X r=a e^{-k t}+(1-a) e^{-k a t}$ \\
\hline Logarithmic & $X r=a_{0}+a e^{-k t}$ \\
\hline Midilli & $X r=a e^{-k t n}+b t$ \\
\hline Two-term & $X r=a_{1} e^{-k 1 t}+a_{2} e^{k 2 t}$ \\
\hline
\end{tabular}

\section{Analysis of soluble dietary fiber and $\beta$-glucan contents}

For comparison purposes, the $\beta$-glucan and soluble dietary fiber contents were determined for the fresh sample as well as the samples that were dried at $35^{\circ} \mathrm{C}, 45^{\circ} \mathrm{C}$, and $55^{\circ} \mathrm{C}$. Samples were homogenized by grounding in a laboratory mixer. The soluble dietary fiber and $\beta$-glucan contents were then determined to verify the influence of temperature on the drying process. Soluble dietary fiber (SDF) was analyzed through the enzymatic-gravimetric method (046/IV) reported by Adolfo Lutz Institute (Brazil, 2008). The weight results were used to calculate the soluble dietary fiber content using Equation 4 (expression for soluble dietary fiber content).

$$
S D F\left(\% \frac{m}{m}\right)=\frac{R T-P-C-B T * 100}{m}
$$

where RT is the total residue of the sample in duplicate (P1-P2) (g), BT is the blank mass (g), P is the sample fiber protein content $(\mathrm{g}), \mathrm{C}$ is the sample ash content $(\mathrm{g})$, and $\mathrm{m}$ is the sample mass $(\mathrm{g})$.

The fiber protein and ash contents were determined for use in Equation 4. To obtain the protein content, the conversion factor (4.38) was multiplied by total nitrogen, which was determined by the micro KJELDAHL method, with the organic material digestion, distillation and then titration, and the calculation given in Equation 5 (expression for total nitrogen).

$$
\text { Total nitrogen }\left(\% \frac{m}{m}\right)=\frac{V * 0.14 * f}{P}
$$

where $\mathrm{V}$ is the hydrochloric acid $(0.1 \mathrm{~N})$ used in the titration and $\mathrm{P}$ is the sample mass $(\mathrm{g})$.

The ash content (fixed mineral residue) was determined through the calcination of $2 \mathrm{~g}$ of sample in porcelain crucibles, in a muffle furnace, at $550{ }^{\circ} \mathrm{C}$, for $3 \mathrm{~h}$, until the complete destruction of the organic matter. The final value was then calculated using Equation 6 (expression for ash content).

$$
\operatorname{Ash}\left(\% \frac{m}{m}\right)=\frac{100 * N}{P}
$$

where $\mathrm{N}$ is the ash mass $(\mathrm{g})$ and $\mathrm{P}$ is the initial sample mass (g).

The $\beta$-glucan content was determined in quadruplicate using an assay kit (K-YBGL/Megazyme ${ }^{\circ}$ Ltd.) according to the manufacturer's instructions (Megazyme $^{\circledR}$; IDA Business Park, Bray, Wicklow, Ireland) and spectrophotometry data were collected to calculate the total glucan, $\alpha$-glucan and $\beta$-glucan contents, using Equations 7 (expression for total glucan content), 8 (expression for $\alpha$-glucan content), and 9 (expression for $\beta$-glucan content).

$$
\begin{aligned}
& \text { Total glucan }\left(\% \frac{m}{m}\right)=\Delta E \quad x \frac{F}{W} \times 90 \\
& \alpha \text { glucan }\left(\% \frac{m}{m}\right)=\Delta E \quad x \frac{F}{W} \times 9.27
\end{aligned}
$$

$$
\beta-\operatorname{glucan}(\%)=(\text { total } \text { glucan })-(\alpha \text { glucan })
$$

where $\Delta \mathrm{E}$ is (sample absorbance) - (blank absorbance), $\mathrm{F}$ is the conversion factor to $\mu \mathrm{g}$ of D-glucose $=100 / \mathrm{blank}$ absorbance, $\mathrm{W}$ is the sample mass, and 90 and 9.27 are the volume correction factors.

Finally, it was necessary to calculate the $\beta$-glucan content in the soluble fiber, since fungal $\beta$-glucans are a 
type of soluble fiber (Equation 10 - expression for sample $\beta$-glucan content in the soluble fiber).

$$
\beta-\text { glucan content }(\%)=\left(\frac{S F C}{100} x \frac{\text { glucan }}{100}\right) \times 100
$$

Statistical analysis of the $\beta$-glucan contents of the samples dried at $35^{\circ} \mathrm{C}, 45{ }^{\circ} \mathrm{C}$ and $55^{\circ} \mathrm{C}$ was performed using the Tukey test ( $\alpha=0.05$ ) to verify the influence of the drying temperature on the $\beta$-glucan content.

\section{RESULTS AND DISCUSSION}

\section{Mushroom drying, equilibrium moisture, and drying curves}

In order to represent the shiitake drying kinetics, the values for the moisture contents on a dry and wet basis were determined using the experimental data for drying at $35^{\circ} \mathrm{C}, 45^{\circ} \mathrm{C}$ and $55^{\circ} \mathrm{C}$. The results obtained were used to plot the graph of moisture content on a dry basis $(\mathrm{X})$ versus drying period $(\mathrm{t})$ shown in Figure 2.

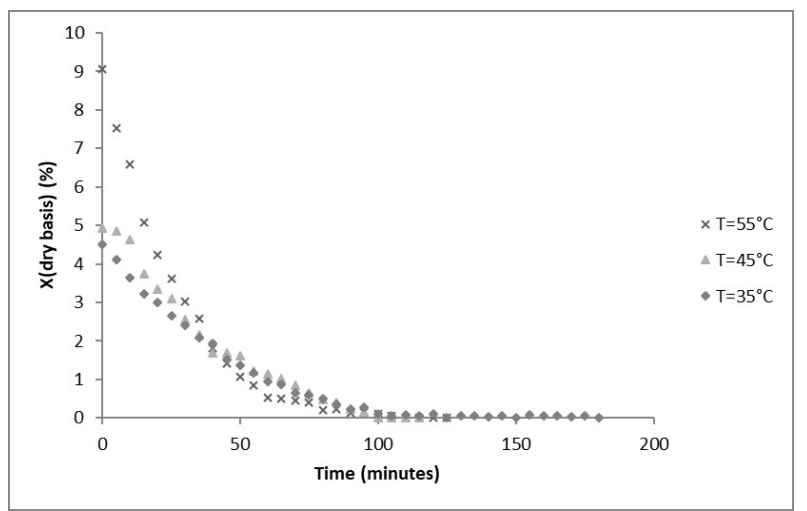

Figure 2: Mushroom moisture variation during drying period.

It can be observed in Figure 2 that the drying process is characterized by a progressive decrease in the moisture content over time, followed by an exponential decay. There is initially a fast reduction in the moisture content due to water loss of the samples while drying, beginning as a result of superficial moisture evaporation (Wang; Zhang; Mujumdar, 2014) and a high heat transfer gradient between the air and the sample (Salehi; Kashaninejad; Jafarianlari, 2017). This is followed by a slow decrease in the moisture loss rate, tending to zero. Furthermore, it is clear in
Figure 2 that the drying temperature significantly affects the total drying period, which decreases as the temperature increases. This relationship can be explained by the fact that high temperatures increase the driving force of mass transfer and accelerate the water vapor diffusion rate (Rhim; Lee, 2011). Time and temperature are also key parameters in relation to maintaining the quality of fruit and vegetables, including edible mushrooms, during the drying process (Qi et al., 2014). Very high temperatures may result in a loss of biological and nutritional properties and affect important characteristics, such as texture, color, and flavor (Das; Arora, 2018; Qi et al., 2014; Salehi; Kashaninejad; Jafarianlari, 2017). On the other hand, very low temperatures increase the drying time and thus the energy consumption of the process (Das; Arora, 2018). Consequently, the selection of the operation parameters for industrial processes is based not only on the energy consumption and technical/economic viability but also the desired properties of the product.

The drying performance observed in this study is consistent with findings in previous studies on the drying of L. edodes using different temperatures and methods. These include hot-air drying, intermediate-infrared drying and vacuum microwave spouted-bed drying at $50^{\circ} \mathrm{C}, 60^{\circ} \mathrm{C}$ and $70^{\circ} \mathrm{C}$ (Qi et al., 2014); mid-infrared-assisted convection drying, hot air coupled with radio frequency drying, hot air coupled with microwave drying and hot air drying at 60 ${ }^{\circ} \mathrm{C}$ (Wang; Zhang; Mujumdar, 2014); microwave-vacuum drying and microwave-vacuum combined with infrared drying (Kantrong; Tansakul; Mittal, 2014); isothermal drying at $55^{\circ} \mathrm{C}$, uniform and non-uniform raise drying at $40^{\circ} \mathrm{C}$, uniform and non-uniform intermittent drying at $55^{\circ} \mathrm{C}$ and combined drying at $40^{\circ} \mathrm{C}$ (Guo et al., 2014); and drying in a tray dryer with temperature control at $48^{\circ} \mathrm{C}$ to 60 ${ }^{\circ} \mathrm{C}$ (Çağlarırmak, 2011). Other edible mushrooms species have also presented similar drying kinetics on using different methods and temperatures for the drying process. Examples include studies on: Agaricus bisporus dried using an integrative system of microwave and convective dryers at $60^{\circ} \mathrm{C}$ (Das; Arora, 2018), infrared-vacuum drying at $70{ }^{\circ} \mathrm{C}$ (Salehi; Kashaninejad; Jafarianlari, 2017), hot air drying and far infrared drying at $60{ }^{\circ} \mathrm{C}$ (Zhang et al., 2016), freeze drying alone and freeze drying combined with microwave vacuum drying at $20^{\circ} \mathrm{C}, 30^{\circ} \mathrm{C}$ and $40^{\circ} \mathrm{C}$ (Pei et al., 2014); convective, microwave, and combined microwave-convective drying at $50^{\circ} \mathrm{C}$ and $75{ }^{\circ} \mathrm{C}$ (Izli; Isik, 2014), drying in a fluidized bed at $45^{\circ} \mathrm{C}, 55^{\circ} \mathrm{C}$ and $65^{\circ} \mathrm{C}$ (Wakchaure et al., 2010); Pleurotus ostreatus dried at $50^{\circ} \mathrm{C}, 60^{\circ} \mathrm{C}$ and $70{ }^{\circ} \mathrm{C}$ (Tulek, 2011); Calocybe indica dried in fluidized bed dryer at $50{ }^{\circ} \mathrm{C}, 70{ }^{\circ} \mathrm{C}$ and $90{ }^{\circ} \mathrm{C}$ 
(Kulshreshtha; Singh; Vipul, 2009); and at $50{ }^{\circ} \mathrm{C}, 55^{\circ} \mathrm{C}$, and $60{ }^{\circ} \mathrm{C}$ (Arumuganathan et al., 2009); and Lentinus squarrosulus Mont. and Pleurotus sajor-caju (Fr.) Singer dried using a controlled hot air dryer at $40{ }^{\circ} \mathrm{C}, 50^{\circ} \mathrm{C}$ and $60{ }^{\circ} \mathrm{C}$ (Duangkhamchan; Wiset; Poomsa-ad, 2013).

Therefore, it is possible to hypothesize that the performance observed in this study is typical of mushroom drying. It is also similar to the behavior of other fruits and vegetables (Onwude et al., 2016; Corrêa et al., 2019). The moisture content plays an important role in the product quality and composition. Thus, it is necessary to ascertain the lowest equilibrium moisture content that is attainable under established drying conditions (Geankoplis, 1993). The determination of this parameter makes it possible to identify the optimum conditions for the product drying process and storage period, which will ensure a stable product, extend the shelf life and reduce microbial contamination risks. Thus, the next step of this study was to determine the equilibrium moisture content (Xe) for each temperature studied using the previously obtained results. The derivative with respect to time was calculated using the polynomial equations obtained from the curves in Figure 2. The graph of the drying velocity $(-\mathrm{dX} / \mathrm{dt})$ versus moisture content on a dry basis $(\mathrm{X})$ was then plotted (Figure 3).

Figure 3 shows the correlation between drying rate and temperature, which increase proportionally. In addition, it can be observed that Shiitake mushroom drying occurs at a decreasing rate during the whole process. This suggests that the process occurs through internal mass transfer by diffusion in the mushroom slices (Geankoplis, 1993; Wang; Zhang; Mujumdar, 2014). Therefore, diffusion appears to be the predominant physical mechanism governing mushroom moisture movement (Tulek, 2011).

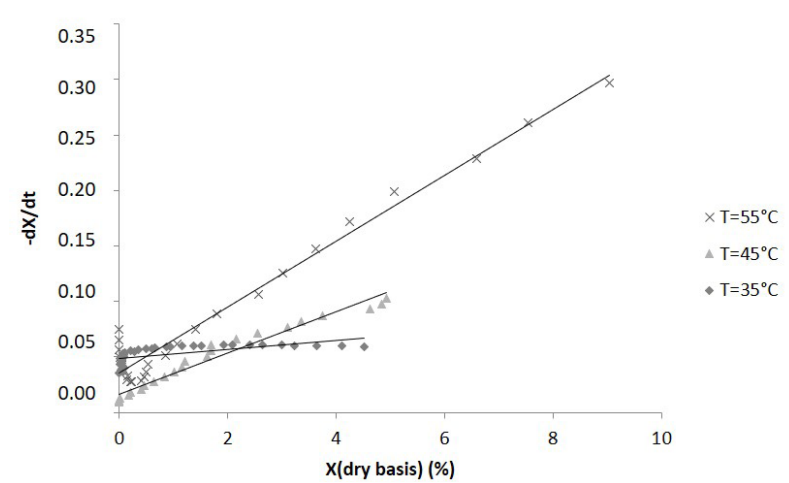

Figure 3: Drying velocity variation against moisture on dry basis content.
These observations are consistent with those of other studies carried out with edodes (Wang; Zhang; Mujumdar, 2014) and different mushroom species, such as Pleurotus ostreatus (Tulek, 2011) and Agaricus bisporus (Wakchaure, 2010) for which similar performance characteristics were noted. Subsequently, using linear regression of the data for the period of decreasing rate in Figure 3, Equations 11 (linear regression equation for $35^{\circ} \mathrm{C}$ ), 12 (linear regression equation for $45^{\circ} \mathrm{C}$ ) and 13 (linear regression equation to $55^{\circ} \mathrm{C}$ ) were obtained. In order to calculate the equilibrium moisture content on a dry basis $(\mathrm{X})$ for each temperature studied, the drying velocity $(-\mathrm{dX} / \mathrm{dt})$ was equal to zero.

$$
\begin{aligned}
& -\frac{d X}{d t}=0.0312 X+0.0273 \\
& -\frac{d X}{d t}=0.0186 X+0.0166 \\
& -\frac{d X}{d t}=0.0509 X+0.0176
\end{aligned}
$$

Table 2 reviews the results obtained from the equilibrium moisture content calculated, the final moisture content obtained from experimental data, and the drying time for each temperature.

As shown in Table 2, the equilibrium value and the final moisture content have similar values. This finding suggests that the experimental data were in agreement with the calculated results for the lowest moisture content attainable under these drying conditions. Furthermore, the moisture content of the samples adhered to commercially acceptable values for dry products, that is, lower than $10 \%$ moisture (dry basis) (Qi et al., 2014). The values for the final sample mass for the three temperatures studied were between 2 and $3 \mathrm{~g}$, which represents a yield of $25 \%$. This low yield indicates the presence of a large amount of water in the composition of the mushrooms (high moisture content), verifying that the Shiitake mushroom is highly perishable. Hence, it is susceptible to microbial growth and enzyme degradation (Qi et al., 2014), emphasizing the importance of employing processes that extend the mushroom shelf life for off-season consumption (Das; Arora, 2018). 
Table 2: Equilibrium and final moisture and drying time for each temperature.

\begin{tabular}{cccc}
\hline Temperature $\left({ }^{\circ} \mathrm{C}\right)$ & Equilibrium moisture $(\%)$ & Experimental final moisture (\%) & Drying time (minutes) \\
\hline 35 & 0.346 & 0.360 & 85.5 \\
45 & 0.892 & 0.840 & 68.6 \\
55 & 0.875 & 0.860 & 54.6 \\
\hline
\end{tabular}

\section{Fitting of mathematical models}

To identify the models that best represent the shiitake drying kinetics for temperatures of $35^{\circ} \mathrm{C}, 45^{\circ} \mathrm{C}$ and $55^{\circ} \mathrm{C}$, the data were converted into dimensionless moisture content $\left(\mathrm{X}_{\mathrm{r}}\right)$. The drying curves were plotted as dimensionless moisture $\left(\mathrm{X}_{\mathrm{r}}\right)$ versus drying time $(\mathrm{t})$, and empirical and semiempirical mathematical models were fitted to these curves using non-linear regression.

All of the models presented a good fit, with determination coefficients $\left(\mathrm{R}^{2}\right)$ higher than 0.94 . Figure 4 (a, b, c, d, e, f) shows the fitting of the Page and Midilli models to the drying curves for each temperature studied. Of the models tested, these two provided the best fit, representing satisfactorily product moisture loss during the drying period, considering the experimental data and using the $\mathrm{R}^{2}$ value as the statistical parameter. According to these data, it can be observed that the Page and Midilli models could represent the drying kinetics of $L$. edodes for the drying conditions applied in this study. These results are in line with those obtained in previous studies carried out with the Shiitake mushroom (Artnaseaw; Theerakulpisut; Benjapiyaporn, 2010; Rhim; Lee, 2011; Salehi; Kashaninejad; Jafarianlari, 2017), as well as other species such as Agaricus bisporus (Pei et al., 2014; Salehi; Kashaninejad; Jafarianlari, 2017), and Pleurotus ostreatus (Tulek, 2011).

However, some authors have found that other models presented the best fit to experimental data for the $L$. edodes drying processes, such as the Modified Page (Kantrong; Tansakul; Mittal, 2014), two-term (Duangkhamchan; Wiset; Poomsa-ad, 2013), and MidilliKucuk (Guo et al., 2014) models. Differences between the drying processes could have led to these findings since the sample drying conditions, such as air velocity, sample dimensions and distribution, balance precision, regression methodology, and mushroom species, can influence the drying kinetics. The drying kinetics can be used to describe the macroscopic and microscopic mechanisms of heat and mass transfer occurring during the drying process, and mathematical models have been applied to describe and predict the drying kinetics (Pei et al., 2014). However, empirical and semiempirical mathematical models should be used with care. It is necessary to evaluate the dataset, the samples, the process parameters, and the expected results, observing the specific characteristics/features of each case. The appropriate choice of drying models is vital since this will affect the equipment design and sizing, process optimization and the product quality (Salehi; Kashaninejad; Jafarianlari, 2017; Zhang et al., 2016). As expected, the results must also be interpreted with caution.

\section{Analysis of soluble dietary fiber and $\beta$-glucan contents}

In order to determine the influence of the drying temperature on soluble dietary fiber and $\beta$-glucan contents, the homogenized fresh and dry samples were analyzed. The fresh mushroom presented $5.73 \pm 0.09 \%$ soluble dietary fiber content and $22.84 \pm 1.40 \% \beta$-glucan content. The results obtained for the dry samples dried at $35^{\circ} \mathrm{C}$, $45^{\circ} \mathrm{C}$ and $55^{\circ} \mathrm{C}$ are summarized in Table 3 .

The Tukey test revealed no significant differences between the mean values for the dietary fiber and $\beta$-glucan contents obtained applying the three temperatures studied. There was also no significant reduction in the $\beta$-glucan content of the dry samples compared with the fresh sample. Thus, overall, the drying temperature did not affect the $\beta$-glucan content in these samples. Therefore, there is a possibility for the maintenance of the properties of this molecule during the drying process under the studied conditions, this emerging as a safe processing alternative.

The Shiitake samples analyzed in this study can be considered as a dietary fiber source since they present values 7 to 8 times higher than those established by WHO/ FAO/UNU (World Health Organization, 2007) to define food rich in dietary fiber (Bach et al., 2017) contributing to human nutrition and health (Çağlarırmak, 2011). Therefore, these results suggest that the consumption of dried Shiitake mushroom dried under the conditions of this study are important to the daily diet and provide approximately $25 \%$ of the recommended dietary fiber ingestion (Fernandes et al., 2015) and could be used as aditives to fortified food products (Çağlarırmak, 2011). 
The dietary fiber values found in this study also exceeded that reported by the technical bulletin of Embrapa (Helm; Coradin; Kestring, 2009) of 36.46\% (dry basis) for $L$. edodes. In addition, this species contains a higher amount

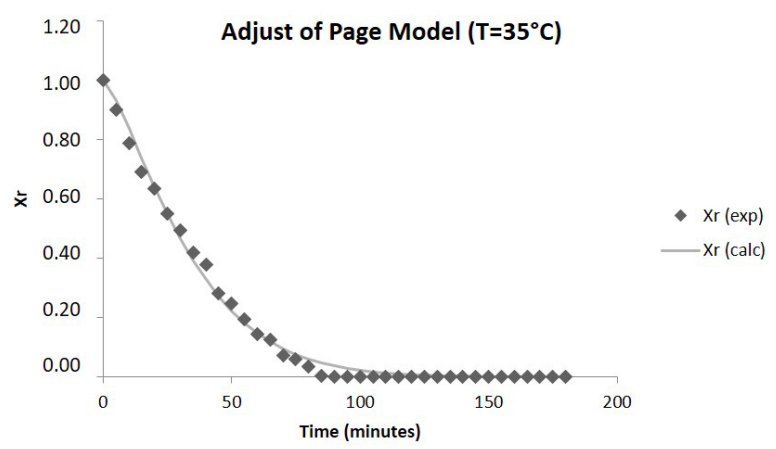

(A)

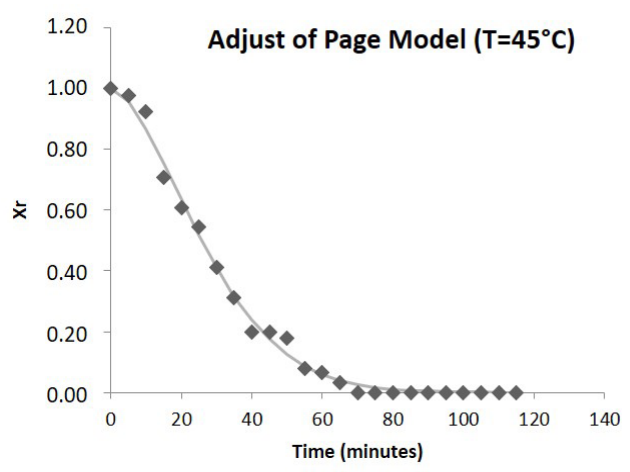

(C)

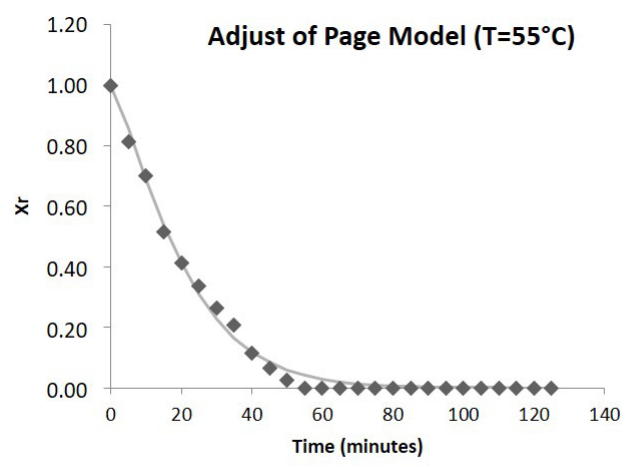

(E)

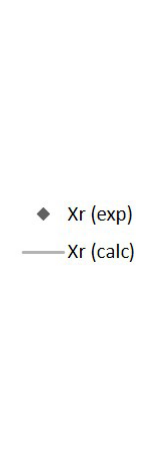

of dietary fiber in comparison with the species Pleurotus ostreatus, Agaricus bisporus, Agaricus portobello, and Agaricus brasiliensis, for which values vary from 21.13 to $21.49 \%$.

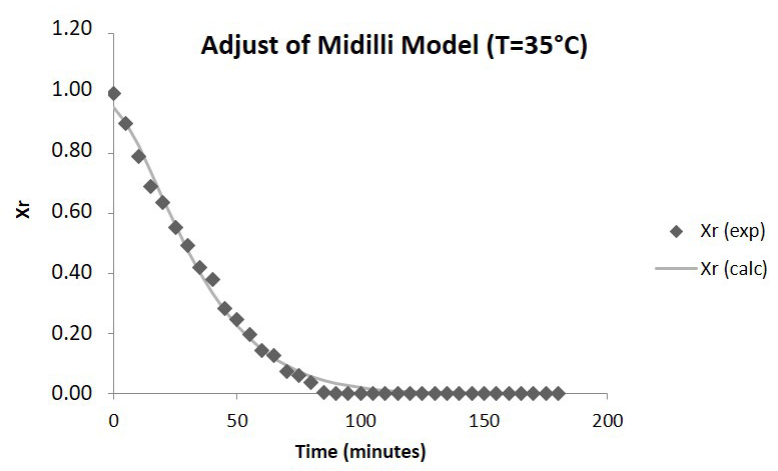

(B)

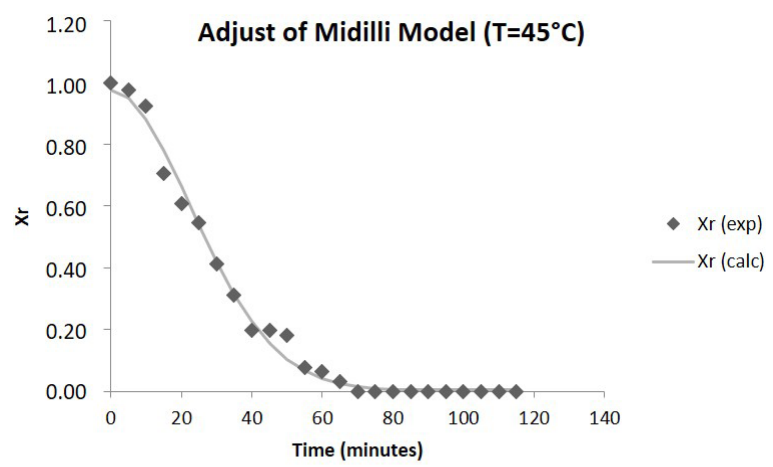

(D)

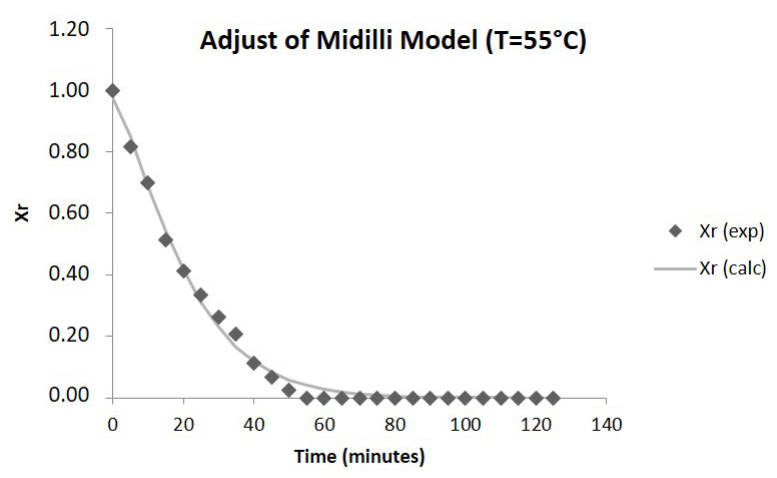

(F)

Figure 4: Adjustment of Page and Midilli models drying curves from $35^{\circ} \mathrm{C}(\mathrm{a}, \mathrm{b}), 45^{\circ} \mathrm{C}(\mathrm{c}, \mathrm{d})$, and $55^{\circ} \mathrm{C}(\mathrm{e}, \mathrm{f})$ temperatures.

Legend: (a) R2 = 0.9943; (b) R2 = 0.9954; (c) R2 = 0.9948; (d) R2 = 0.9922; (e) R2 = 0.9946; (f) R2 = 0.9949 . 
Table 3: Results of fiber and glucan analyses from dry shiitake samples.

\begin{tabular}{cccccccc}
\hline $\begin{array}{c}\text { Temp. } \\
\left({ }^{\circ} \mathrm{C}\right)\end{array}$ & $\begin{array}{c}\text { Total } \\
\text { fiber } \\
(\%)\end{array}$ & $\begin{array}{c}\text { Insoluble } \\
\text { fiber } \\
(\%)\end{array}$ & $\begin{array}{c}\text { Soluble fiber } \\
(\text { dry basis, \%) }\end{array}$ & $\begin{array}{c}\text { Total glucan } \\
(\%)\end{array}$ & $\begin{array}{c}\text { Alpha glucan } \\
(\%)\end{array}$ & $\begin{array}{c}\text { Beta } \\
\text { glucan } \\
(\%)\end{array}$ & $\begin{array}{c}\text { Beta glucan/ } \\
\text { soluble fiber (\%) }\end{array}$ \\
\hline 35 & $41.25 \pm 1.98$ & $34.90 \pm 2.60$ & $6.78 \pm 0.70$ & $22.38 \pm 0.48$ & $0.38 \pm 0.01$ & $21.99 \pm 0.48$ & $1.49 \pm 0.19$ \\
45 & $40.91 \pm 0.70$ & $34.72 \pm 0.57$ & $6.60 \pm 0.15$ & $23.57 \pm 0.41$ & $0.29 \pm 0.00$ & $23.28 \pm 0.41$ & $1.54 \pm 0.01$ \\
55 & $40.79 \pm 0.70$ & $35.24 \pm 1.26$ & $5.88 \pm 0.62$ & $24.15 \pm 0.18$ & $0.50 \pm 0.02$ & $23.65 \pm 0.16$ & $1.39 \pm 0.16$ \\
\hline
\end{tabular}

In a study on nine edible mushroom species from the genera Agaricus, Flammulina, Lentinula, and Pleurotus, Bach et al. (2017) observed that the dietary fiber content varied between $24.47 \%$ for $A$. bisporus (Portobello) and $46.62 \%$ for P. ostreatus (white oyster). Pleurotus and Lentinula presented higher values than Agaricus and Flammulina, and for L. edodes the value was $41.89 \%$, one of the highest and similar to that obtained in this study. On the other hand, Guo et al. (2014) noted lower values, varying between 28.37 and $32.64 \%$, and in Çağlarırmak (2011) study, the dried shiitake samples showed about $23.23 \%$ of dietary fiber content. The discrepancy observed in the dietary fiber contents may be due to genetic factors that determine the quantity and the type of saccharides on the fungal cell wall (Henriques et al., 2016). The fibrillar components that constitute the fungal cell wall include $\beta$-glucan polysaccharides, which represent approximately $50 \%$ of the call wall in mushrooms (Valverde; HérnandezPérez; Paredes-López, 2015), and L. edodes is recognized as one of the most important sources of $\beta$-glucan from mushrooms (Sari et al., 2017).

As in the case of the dietary fiber content, the $\beta$-glucan content obtained in this study is significantly high, however, it is not common for $\beta$-glucan content fiber to be determined through the calculation used in this study (calculated in relation to soluble dietary fiber). Therefore, in order to compare the $\beta$-glucan contents, the results of 21.99 to $23.65 \%$ (dry basis) were considered. The $\beta$-glucan contents observed in this investigation are below those observed by other authors, for instance, 20.06 to $44.21 \%$ (Bak et al., 2014), 26-27\% (Kim et al., 2010), 41.2 (Kozarski, 2012), between 29.74 and $56.28 \%$ (Bak et al., 2014), and 27.4\% and 23.5\% (McCleary; Draga, 2016). Nevertheless, some previously reported results are similar to or lower than those obtained in this study, for instance, $19.779 \%$ (Sari et al., 2017), 23.5\% (McCleary; Draga, 2016), and $11.63 \%$ (Henriques et al., 2016). Furthermore, in a study with nine different edible mushroom species from the genera Agaricus, Flammulina, Lentinula and Pleurotus, Bach et al. (2017) obtained $\beta$-glucan contents between 1.58 and $16.91 \%$ (dry basis), and L. edodes was one of the species that presented higher $\beta$-glucan content (11.63\%). Similarly, Sari et al. (2017) quantified the $\beta$-glucan content of 39 mushrooms, and $L$. edodes presented one of the highest values $(19.779 \%)$. Overall, these findings suggest that the Shiitake mushroom has good potential in terms of supplying dietary fiber and $\beta$-glucans.

In mushrooms, $\beta$-glucans are one of the most important components of the cell wall (Bach et al., 2017; Zhu et al., 2015) and they are recognized as its potential immunostimulating and immunosuppressing effects (Wasser, 2017). These compounds are not synthesized in the human body and for this reason they are not recognized by the immune system as safe molecules and, consequently, induce innate and adaptive immune responses (Graubaum, 2012). These molecules have bioactive properties, such as immunomodulatory activity (Sari et al., 2017) and can be part of oncoimmunological adjuvant therapy against cancer (Wasser, 2017), as well as antioxidant, neuroprotective (Henriques et al., 2016), hepato-protective, antimicrobial, antiallergic, antiinflammatory (Chang; Wasser, 2018), antiatherogenic, antidiabetic, cardiovascular and radioprotective (Zhu et al., 2015) effects, used by cosmetic, pharmacological and dietary supplements companies. The $\beta$-glucan content varies according to the mushroom species (L. edodes and Pleutorus spp. are considered the most important sources), as well as the cultivation conditions and fruiting body maturity (Rop; Mlcek; Jurikova, 2009). These results, therefore, need to be interpreted with caution. Moreover, the temperature is known to be an important parameter in all mushroom processing stages but there is limited information available on the thermoresistance of $\beta$-glucans (Kagimura et al., 2015).

Carbohydrates are relatively sensitive to temperatures higher than room temperature, which could result in the degradation of $\beta$-glucan and the loss of its biological activity (Kagimura et al., 2015). This degradation of carbohydrates was proved by Radzki 
et al. (2019) when they dried fruiting bodies of five wild-growing edible species using hot-air drying and may lead to substantial decline in the content of watersoluble polysaccharides. It is necessary, therefore, to investigate the limitations of the $\beta$-glucan molecule and its resistance in relation to temperature, in order to improve the edible mushroom processing techniques and conserve the physical, nutritional and medicinal properties of the product. Further research should be carried out to establish limitations and investigate the thermoresistance of $\beta$-glucan molecules.

The data reported in this study suggest that the chemical composition of $L$. edodes was not significantly influenced by the drying temperature in terms of dietary fiber and $\beta$-glucan content. It is possible that this tendency toward stability is because the water is difficult to remove by drying processes using the temperatures studied and these molecules continue to be strongly associated with other molecules through hydrogen bonds, particularly macromolecules such as proteins and polysaccharides, which are hard to break under the studied conditions (Guo et al., 2014). Therefore, since no significant alteration in the $\beta$-glucan content occurred at the temperatures studied, $55^{\circ} \mathrm{C}$ can be recommended as the optimum temperature for the Shiitake mushroom drying process. This temperature provides the shortest drying time and could be an effective alternative for achieving energy savings and lower process costs (Zhu et al., 2015). This is consistent with the findings of Wakchaure et al. (2010) who observed that this drying temperature led to the best product quality in terms of color, texture, crispiness, flavor, and shrinkage, compared to higher temperatures. In addition, the application of higher temperatures for longer durations could damage the nutrients present in the dried mushroom (Das; Arora, 2018).

\section{CONCLUSIONS}

The application of drying techniques to allow a longer shelf life and maintain the product quality plays an important role from the commercial viewpoint. The kinetics of food drying is complex and influenced by many factors that are interconnected non-linearly. This study showed that the temperature is inversely proportional to the drying time. In addition, the exposure of shiitake mushroom at a temperature of $55{ }^{\circ} \mathrm{C}$ did not significantly affect the $\beta$-glucan content. According to the literature, the soluble polysaccharide content decreases during drying processes carried out at $60^{\circ} \mathrm{C}$, such as $\beta$-glucans. Thermal changes in nutritional composition and molecules with biological activity reduce the healthiness of dehydrated products. Mathematical models can be used to investigate and to predict the moisture behavior during the drying process. In this study, the Page and Midilli models provided the best fits with the experimental data, acceptably describing the Shiitake drying process. Information on the drying kinetics is vital for equipment design, process simulations and the optimization of drying parameters and processes.

\section{ACKNOWLEDGEMENTS}

The authors are thankful to the Support for Scientific and Technological Research Foundation of Santa Catarina State (FAPESC) for financial support. This study was financed in part by the Coordination for the Improvement of Higher Education Personnel - Brasil (CAPES) - Finance Code 001. The author LBB Tavares is fellowship holder of the National Council for Scientific and Technological Development (CNPq).

\section{REFERENCES}

ARTNASEAW, A.; THEERAKULPISUT, S.; BENJAPIYAPORN, C. Drying characteristics of shiitake mushroom and jinda chili during vacuum heat pump drying. Food and Bioproducts Processing, 88(2-3):105-114, 2010.

ARUMUGANATHAN, T. et al. Mathematical modeling of drying kinetics of milky mushroom in a fluidized bed dryer. International Agrophysics, 23(1):1-7, 2009.

$B A C H, F$. et al. Edible mushrooms: A potential source of essential amino acids, glucans and minerals. International Journal of Food Science \& Technology, 52(11):2382-2392, 2017.

BAK, W. C. et al. Determination of glucan contents in the fruiting bodies and mycelia of Lentinula edodes cultivars. Mycobiology, 42(3):301-304, 2014.

BETORET, E. et al. Functional foods development: Trends and technologies. Trends in Food Science and Technology, 22(9):498-508, 2011.

BIGLIARDI, B.; GALATI, F. Innovation trends in the food industry: The case of functional foods. Trends in Food Science and Technology, 31(2):118-129, 2013.

BRAZIL. Instituto Adolfo Lutz (São Paulo - Brasil). Métodos físico-químicos para análise de alimentos: Normas analíticas do Instituto Adolfo Lutz. 4. ed. [1. ed. digital]. São Paulo (SP): Instituto Adolfo Lutz; 2008. Available in: <http:// www.ial.sp.gov.br/resources/editorinplace/ial/2016_3_19/ analisedealimentosial_2008.pdf>. Access in: July, 27, 2019. 
ÇAĞLARIRMAK, N. Chemical composition and nutrition value of dried cultivated culinary-medicinal mushrooms from Turkey. International Journal of Medicinal Mushrooms, 13(4):351-356, 2011.

CHANG, S. T.; WASSER, S. P. Current and future research trends in agricultural and biomedical applications of medicinal mushrooms and mushroom products. International Journal of Medicinal Mushrooms, 20(12):1121-1133, 2018.

CHANG, S. T.; WASSER, S. P. The role of culinary-medicinal mushrooms on human welfare with a pyramid model for human health. International Journal of Medicinal Mushrooms, 14(2):95-134, 2012.

CORRÊA, P. C. Dehydration of infrared ginger slices: Heat and mass transfer coefficient and modeling. Science and Agrotechnology, 43(e025318):1-11, 2019.

DAS, I.; ARORA, A. Alternate microwave and convective hot air application for rapid mushroom drying. Journal of Food Engineering, 223(1):208-219, 2018.

DUANGKHAMCHAN, W.; WISET, L.; POOMSA-AD, N. Evaluation of drying and moisture sorption characteristics models for shiitake mushroom (Lentinus squarrosulus Mont.) and grey oyster mushroom (Pleurotus sajor-caju (Fr.) Singer). Suranaree. Journal of Science and Technology, 20(2):151-166, 2013.

FERNANDES, Â. et al. Exquisite wild mushrooms as a source of dietary fiber: Analysis in electron-beam irradiated samples. LWT-Food Science and Technology, 60(2):855-859, 2015.

GEANKOPLIS, C. J. Transport processes and unit operations. 3 ed. Englewood Cliffs, NJ: Prentice Hall, 1993. 921p.

GRAUBAUM, H. J. A double-blind, randomized, placebocontrolled nutritional study using an insoluble yeast betaglucan to improve the immune defense system. Food and Nutrition Sciences, 03(6):738-746, 2012.

GUO, X. H. et al. Mathematical modeling and effect of various hot-air drying on mushroom (Lentinus edodes). Journal of Integrative Agriculture, 13(1):207-216, 2014.

HELM, C. V.; CORADIN, J. H.; KESTRING, D. Avaliação da composição química dos cogumelos comestíveis Agaricus bisporus, Agaricus brasiliensis, Agaricus bisporus portobello, Lentinula edodes e Pleorotus ostreatus. In: HELM, C. V.; CORADIN, J. H.; KESTRING, D. Comunicado Técnico 235, Embrapa Florestas: Brasil, 2009, p.1-7.

HENRIQUES, G. S. et al. Lipid profile and glycemic response of rats fed on a semi-purified diet supplemented with
Agaricus brasiliensis mushroom. Acta Scientiarum. Health Sciences, 38(1):71-79, 2016.

IZLI, N.; ISIK, E. Effect of different drying methods on drying characteristics, colour and microstructure properties of mushroom. Journal of Food and Nutrition Research, 53(2):105-116, 2014.

KAGIMURA, F. Y. et al. Biological activities of derivatized d-glucans: A review. International Journal of Biological Macromolecules, 72(1):588-598, 2015.

KANTRONG, H.; TANSAKUL, A.; MITTAL, G. S. Drying characteristics and quality of shiitake mushroom undergoing microwave-vacuum drying and microwavevacuum combined with infrared drying. Journal of Science and Technology, 51(12):3594-3608, 2014.

$\mathrm{KIM}$, J. et al. Particle size effect of Lentinus edodes mushroom (CHAMSONG-I) powder on the physicochemical, rheological, and oil-resisting properties of frying batters. Journal of Texture Studies, 41(1):381-395, 2010.

KOZARSKI, M. et al. Antioxidative activities and chemical characterization of polysaccharide extracts from the widely used mushrooms Ganoderma applanatum, Ganoderma lucidum, Lentinus edodes and Trametes versicolor. Journal of Food Composition and Analysis, 26(1-2):144-153, 2012.

KULSHRESHTHA, M.; SINGH, A.; VIPUL, D. A. Effect of drying conditions on mushroom quality. Journal of Engineering Science and Technology, 4(1):90-98, 2009.

LENZI, J. et al. Medicinal fungi: A source of antiparasitic secondary metabolites. Applied Microbiology and Biotechnology, 102(14):5791-5810, 2018.

MAISNAM, D. et al. Recent advances in conventional drying of foods. Journal of Food Technology and Preservation, 1(1):25-34, 2017.

MCCLEARY, B. V.; DRAGA, A. Measurement of $\beta$-glucan in mushrooms and mycelial products. Journal of AOAC International, 99(2):364-373, 2016.

ONWUDE, D. I. et al. Modeling the thin-layer drying of fruits and vegetables: A review. Comprehensive Reviews in Food Science and Food Safety, 15(3):599-618, 2016.

PEI, F. et al. Comparison of freeze-drying and freeze-drying combined with microwave vacuum drying methods on drying kinetics and rehydration characteristics of button mushroom (Agaricus bisporus) slices. Food and Bioprocess Technology, 7(6):1629-1639, 2014. 
QI, L. L. et al. Comparison of drying characteristics and quality of shiitake mushrooms (Lentinus edodes) using different drying methods. Dry Technology, 32(15):1751-1761, 2014.

RADZKI, W. et al. The impact of drying of wild-growing mushrooms on the content and antioxidant capacity of water-soluble polysaccharides. International Journal of Medicinal Mushrooms, 21(4):393-400, 2019.

RHIM, J-W.; LEE, J. H. Drying kinetics of whole and sliced shiitake mushrooms (Lentinus edodes). Food Science and Biotechnology, 20(1):419-427, 2011.

ROP, O.; MLCEK, J.; JURIKOVA, T. Beta-glucans in higher fungi and their health effects. Nutrition Research, 67(11):624631, 2009.

SALEHI, F.; KASHANINEJAD, M.; JAFARIANLARI, A. Drying kinetics and characteristics of combined infrared-vacuum drying of button mushroom slices. Heat and Mass Transfer, 53(5):1751-1759, 2017.

SARI, M. et al. Screening of beta-glucan contents in commercially cultivated and wild growing mushrooms. Food Chemistry, 216(1):45-51, 2017.

SOUSA, M. A. C. et al. Enzyme activity and biochemical changes during production of Lentinula edodes (Berk.) Pegler. Food Science and Technology, 39(3):774-780, 2019.

TULEK, Y. Drying kinetics of oyster mushroom (Pleurotus ostreatus) in a convective hot air dryer. Journal of Agricultural Science and Technology, 13(1):655-664, 2011.
VALVERDE, M. E.; HERNÁNDEZ-PÉREZ, T.; PAREDES-LÓPEZ, O. Edible mushrooms: Improving human health and promoting quality life. International Journal of Microbiology, 7(14):1-13, 2015.

WAKCHAURE, G. C. et al. Kinetics of thin layer drying of button mushroom. Journal of Agricultural Engineering, 47(4):4146, 2010.

WANG, H.; ZHANG, M.; MUJUMDAR, A. S. Comparison of three new drying methods for drying characteristics and quality of shiitake mushroom (Lentinus edodes). Dry Technology, 32(15):1791-1802, 2014.

WASSER, S. P. Medicinal mushrooms in human clinical studies. Part I. Anticancer, oncoimmunological, and immunomodulatory activities: A review. International Journal of Medicinal Mushrooms, 19(4): 279-317, 2017.

WORLD HEALTH ORGANIZATION. Report of a Joint WHO/ FAO/UNU, Protein and amino acid requirements in human nutrition. Geneva, 2007 (Technical report series 935). Available in: <https://apps.who.int/iris/ bitstream/handle/10665/43411/WHO_TRS_935_eng. pdf?sequence=1\&isAllowed=y>. Access in: July, 22, 2019.

ZHANG, Z. et al. Effects of ultrasound pretreatment on drying kinetics and quality parameters of button mushroom slices. Dry Technology, 34(15):1791-1800, 2016.

ZHU, F. et al. Beta-glucans from edible and medicinal mushrooms: Characteristics, physicochemical and biological activities. Journal of Food Composition and Analysis, 41(1):65-173, 2015. 